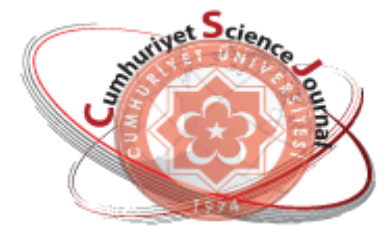

e-ISSN: $2587-246 X$

ISSN: $2587-2680$

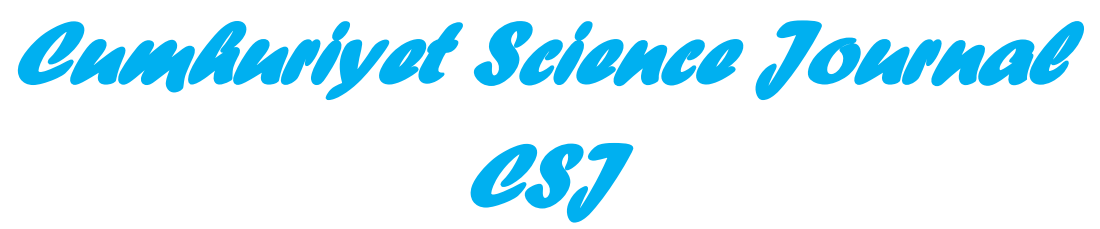

Cumhuriyet Sci. J., Vol.40-3(2019) 679-694

\title{
The Comparison of Primary, Secondary and Tertiary Amine Ligands on Palladium (II) Complex Ion on Thermo-Physical, Chemical Reactivity, and Biological Properties: A DFT Study
}

\author{
Mohammad Jahidul ISLAM ${ }^{1}$ (D), Md. Nuruzzaman SARKER ${ }^{1}$ (D), Ajoy KUMER ${ }^{2, *}$ (D), Sunanda \\ PAUL ${ }^{3, *}$ \\ ${ }^{1}$ Department of Physics, European University of Bangladesh, Dhaka-1216, Bangladesh \\ ${ }^{2}$ Department of Chemistry, European University of Bangladesh, Dhaka-1216, Bangladesh \\ ${ }^{3}$ Department of Biochemistry and Molecular Biology, University of Chittagong, Chittagong, Hathazari-4334, \\ Bangladesh
}

\begin{abstract}
The Palladium is considered as the catalyst for coupling reaction and useful metal in industry. The thermo-physical, chemical reactivity and biological interaction are considered the most expected parameters for use in any area of the chemical industry, the pharmaceutical industry, and academia. The palladium (II) complex ion with different amine ligands are considered under theoretical study by the method of density functional theory (DFT). Some thermo-physical parameters such as free energy, entropy, dipole moment, binding energy, nuclear energy, electronics energy, heat of formation, reactivity properties of molecule like Highest Occupied Molecular Orbital (HOMO), Lowest Unoccupied Molecular Orbital (LUMO), HOMO-LUMO gap, ionization potential, electronegativity, hardness, softness and electron affinity, and biological properties of molecules like charge density, surface area grid, volume, LogP, polarizibility, refractivity, molecular mass, PIC50 were calculated using the computational program of DFT method. The value of HOMO LUMO gap is 10.78, 0.59, 0.50 , and 10.73 and PIC50 is $-20.41,-8.46,-1.69$, and 1.83 for L01, L02, L03, and L04 respectively while the chemical stability is same for L02, and L03, similarly L01 and L04. The QSAR study provides information about their correlation and biological activity as drugs whereas the biological activity was increased with increasing methyl groups. The four palladium (II) complex ions with amine ligands have strong biological activity for L03 and L04, and occur the correlation on thermophysical, chemical reactivity.
\end{abstract}

Keywords: Palladium, alkylamine, QSAR, HOMO, LUMO, vibrational spectroscopy and PIC50

Palladium (II) Kompleks İyondaki Primer, Sekonder ve Tersiyer Amin Ligandlarının Termo-Fiziksel, Kimyasal Reaktivite ve Biyolojik Özelliklerle Karşılaştırılması: DFT Çalışması

\footnotetext{
Özet. Palladyum kenetlenme reaksiyonları için katalizör olarak dikkate alınır ve sanayide kullanışlı bir metaldir. Termo-fiziksel, kimyasal reaktivite ve biyolojik etkileşim, kimya endüstrisi, ilaç endüstrisi ve akademi de en çok dikkate alınan parametrelerdir. Farklı amin ligandları içeren Pd (II) kompleks iyonu, çalışmanın teorik kısmında DFT yöntemi kullanılarak incelenmiştir. Serbest enerji, entropi, dipol moment, bağlanma enerjisi, nükleer enerji, elektronik enerji, oluşum 1sısı gibi termo-fiziksel parametreler, HOMO enerjisi, LUMO enerjisi, HOMO-LUMO enerji aralığı, iyonlaşma enerjisi, elektronegatiflik, sertlik, yumuşaklık ve elektron ilgisi gibi reaktivite özellikleri, yük yoğunluğu, yüzey alanı, hacim $\log P$, Polarlanabilirlik, refraktivite, moleküler kütle, PIC50 gibi biyolojik özellikleri DFT methodu yardımıyla hesaplanmıştır. L01, L02, L03 ve L04 için HOMOLUMO enerji aralığ değerleri $10.78,0.59,0.50$ ve 10.73; PIC50 değerleri sırasıyla $-20.41,-8.46,-1.69$ ve 1.83 tür. L02 ile L03 ün, L02 ile L04 ün kimyasal kararlılıkları hemen hemen aynıdır. QSAR çalışması moleküllerin
} 
biyolojik aktiflikleri hakkında bilgi sağlar. Amin ligandlarını içeren dört Pd(II) kompleks iyonu L03 ve L04 için güçlü biyolojik aktiviteye sahiptir.

Anahtar Kelimeler: Palladyum, alkil amin, QSAR, HOMO, LUMO, titreşim spektroskopisi ve PIC50

\section{INTRODUCTION}

Palladium is a soft, rare, silvery-white metal that is valued for its catalytic properties and shares many of the characteristics common to the platinum group metal [1]. It has a face-centered cubic crystalline structure at ordinary temperatures and it is strongly resistant to corrosion in the air and to the action of an acid. The largest uses of palladium are as metal in the field of jewelry [2], dentistry, watch making, blood sugar test strips, aircraft spark plugs, surgical instruments, and electrical contacts [3]. On the other hand, these are currently attracted considerable interest because they're potentially beneficial as pharmaceutical ingredients, a bioactive molecule, pharmacological properties [4-6]. Palladium complexes have been worked against cancer cells [7-9]. However, although palladium has less cytotoxic effects than platinum, palladium has good cytotoxic effects as well for use as bioactive molecules of the area drug design $[10,11]$. Palladium complexes with aromatic $\mathrm{N}$-containing ligands, e.g., derivatives of amine, pyridine, quinoline, pyrazole, and 1, 10-phenanthroline has shown very promising antitumor characteristics molecules. Some of these complexes, especially the trans complexes with non-planar heterocyclic amine ligands have been found to overcome multifactorial cis platin resistance in human ovarian cell lines. On the other hand, $\mathrm{Pd}(\mathrm{II})$ complexes or complex ions have been widely explored due to their catalytic efficiency, e.g., for various carbon-carbon and carbon-nitrogen bondforming reactions. The most palladium (0), palladium (II) on carbon makes some versatile catalyst of organic syntheses such as Heck reaction, Suzuki coupling, Tsuji-Trost reactions, Wacker process, Negishi reaction and Stille coupling, etc [12-15]. While most studies of palladium have concentrated on the reactivity of its complexes, little information about their electronic structures has been obtained.
Organometallic transition-metal complexes utilizing nitrogen ligands with ionic or polar substituent have been found to catalyze a large variety of chemical transformations in aqueous solution. Palladium is one of the most catalytically versatile transition metal. The nitrogen-containing ligand assisted palladium catalyzed Suzuki coupling reaction is the most frequently employed methods of carbon-carbon bond formation in organic synthesis [14]. In the literature, the molecular structure of a complex containing palladium atom have been studied for years, however electronic structure of this molecule have been worked out quite a bit.

Taking into account all the benefits in thermophysical, chemical reactivity, biological profile, the computational chemistry is the best tools in present time of chemistry, physics, material science, pharmaceutical science, molecular engineering, and biochemistry. To save time and cost, computational computer programming is used on making the correlation of the thermophysical, chemical and biological activity of some palladium complexes. A thermodynamic system is a definite macroscopic area or space in the universe in which one or more thermodynamic processes take place. This system has a specific volume consisting of molecules and atoms with continuous movement and concussion by the interaction with the external surrounding. The internal properties and its interaction with the surrounding determine the system behavior [16-18].

A thermodynamic system can switch from initial state through the intermediate state to the final state which is called transformation of state or thermodynamics process $[17,19]$. Using the computational simulation of the examined palladium complexes, It would be calculated by the various method of computational methods. As 
the anion has an effective influence on biological activity, the relationship of substituent group in benzene rings was estimated using computing parameters [20, 21]. The most beneficial of the study is the safe the money including conducting a chemical experiment in laboratory and consumption of time in the laboratory at which the most errorless method is the Density functional theory (DFT) [22, 23].

The Density functional theory (DFT) finds an increasingly broad application in the chemical and materials sciences for the interpretation and prediction of complex system behavior at an atomic scale. Specifically, DFT computational methods are applied for the study of systems to synthesis and processing parameters. The Density Functional Theory (DFT) is used to determine chemical structures of molecules and structural changes in molecules. Especially, the B3LYP method is widely used because it yields results very close to experimental results. Moreover, the DFT is a very useful method for predicting the experimental results.

In this study, the palladium (II) complex was synthesized and optimized with DFT/B3LYP. Some geometrical parameters and HOMOLUMO energy level of the complex were calculated at B3LYP. Their molecular structural relationship, HOMO, LUMO, and quantum chemical properties and LogP plays the role of the chemical reactivity, biological activity and hydrophobicity and hydrophobicity of chemicals in relation with living cells activity and associated mechanistic interactions.

\section{COMPUTING METHODS FOR SIMULATION}

The molecular modeling program permits to build and analyze different molecular structures and determine the molecular, electronic, and biological properties. In order to create the spatial chemical structure of each calculated molecule, the twodimensional structure of the molecule shall be built step-by-step by drawing. Then hydrogen atoms are automatically added from building option and chemical structure is converted into a $3 \mathrm{D}$ structure.
The first step in getting the main characteristic parameters of molecules is to optimize the molecular structure to obtain a configuration characterized by minimum free energy. In sitting the DFT was fixed via 6G-31G*, and B3-LYP [2426]. After completing optimization, the theoretical properties of the studied compound such as free energy, entropy, dipole moment, binding energy, nuclear energy, electronics energy, the heat of formation, the HOMO, LUMO are recorded. The QSAR properties of molecules like charge density, surface area grid, volume, LogP, polarizability, refractivity, molecular mass, were calculated.

\section{RESULTS AND DISCUSSIONS}

\subsection{Optimized Structure}

The symmetry is a very powerful tool to establish the molecular symmetry calculation. In fig-01, Tetraamine palladium (II) complexes ion (L01), Tetra(methylamine) palladium (II) complexes ion (L02), Tetra(dimethylamine) palladium (II) complexes ion (L03) and Tetra(trimethylamine) palladium (II) complexes ion (L04) molecular orbital diagram having both of molecular symmetry and asymmetry properties are represented.

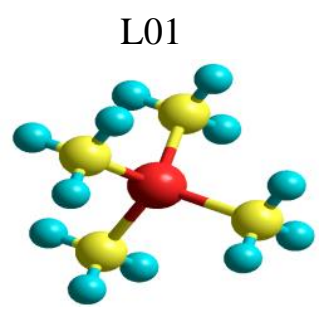

L03

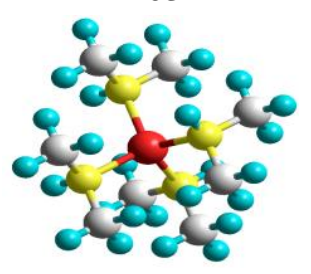

L02

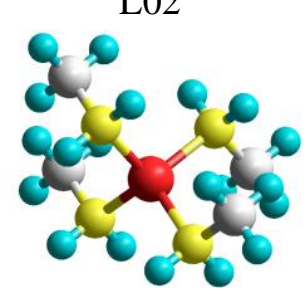

L04

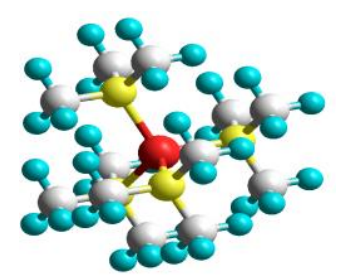

Figure 1. Optimized structure of palladium (II) complex ions with different amine ligands

\subsection{Bond Length}

In general, the bond length between two atoms is approximately the sum of the covalent radii of the two atoms. For covalent bonds, bond energies and bond lengths depend on many factors like electron affinities, sizes, electronegativity, chemical 
reactivity, ionization potential, and chemical stability of atoms involved in the bond. The bond length of atoms in complexes ions are given in fig-

\section{L01}

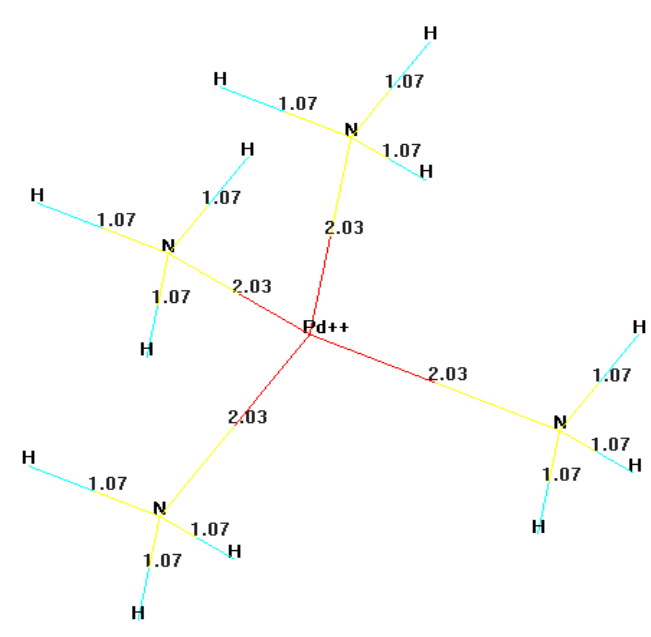

L03

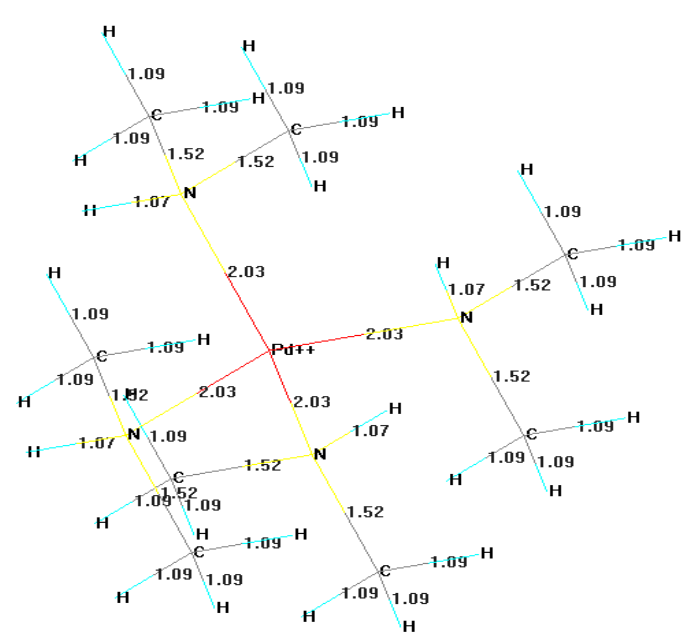

02. The bond length in palladium (II) with nitrogen is 2.03 for all complexes.

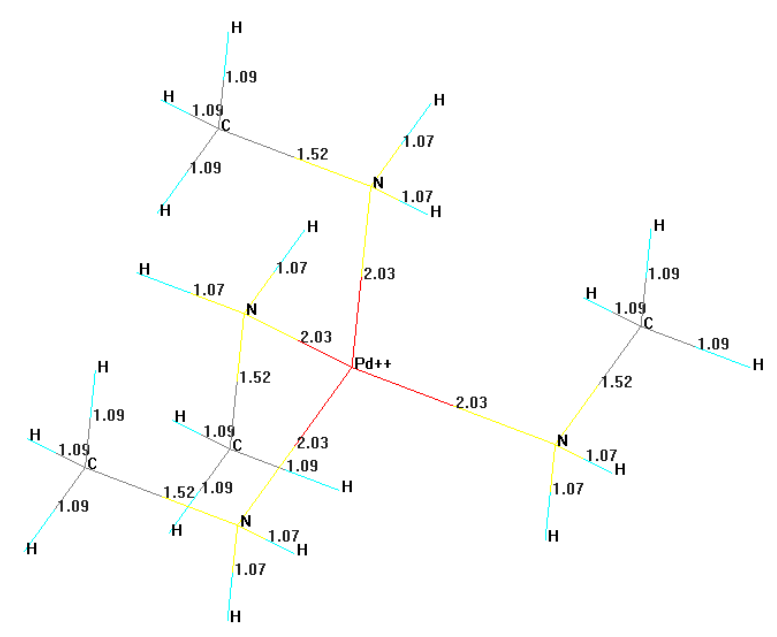

\section{L04}

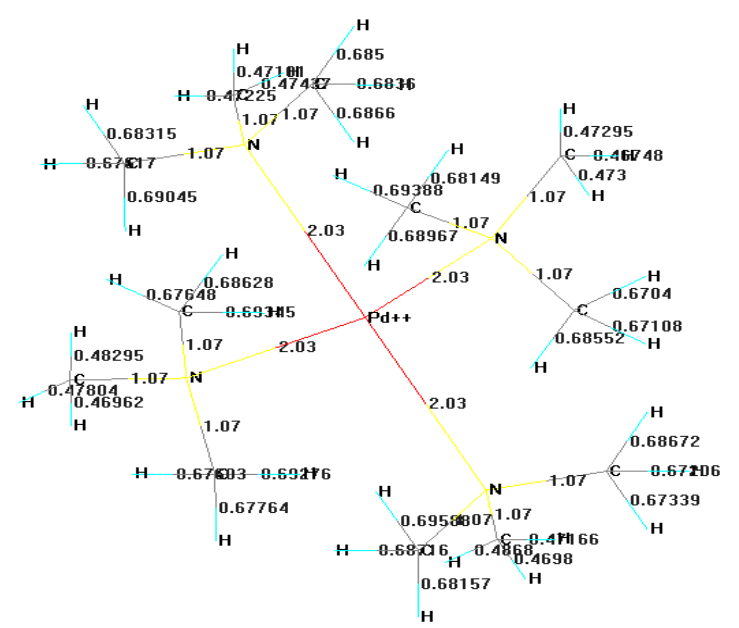

Figure 2. Bond length of palladium (II) complex ions with different amine ligands

\subsection{Bond Order}

The bond order indicates the chemical stability. The higher the bond order indicates the stronger the pull between the two atoms and the shorter the bond length. The shorter bond length indicates the higher required energy, as a result, the rate of reaction decreases and chemical reactivity decreases [27]. From figure 03, the bond order between all atoms in a molecule is obtained in same and that is one.

\subsection{The Atomic Charges}

The atomic charge is the most important parameters for calculation of thermophysical properties and thermodynamics shown in fig 4 . In L01, the atomic charge of palladium atom is 1.057 , and a nitrogen atom in amine ligands almost 0.300 to 0.397 and carbon atom in the methyl group is 3.96 to 3.99 . 


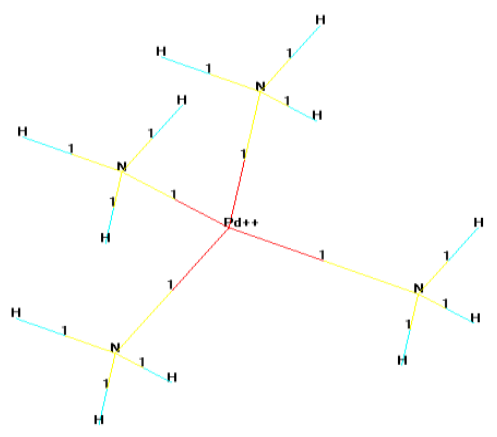

L03

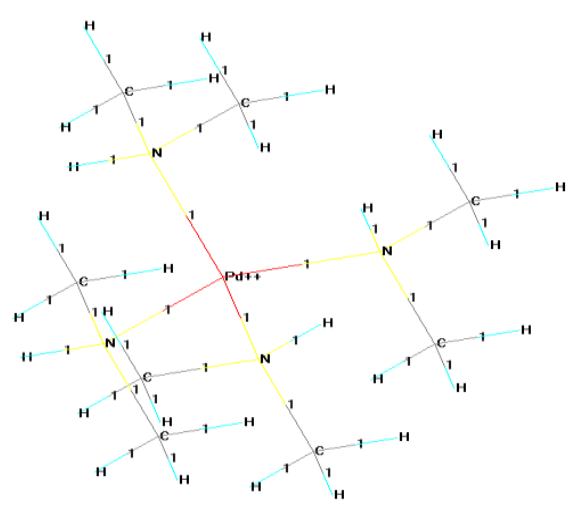

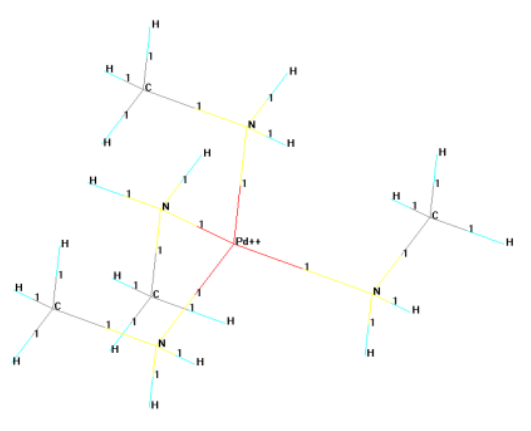

L04

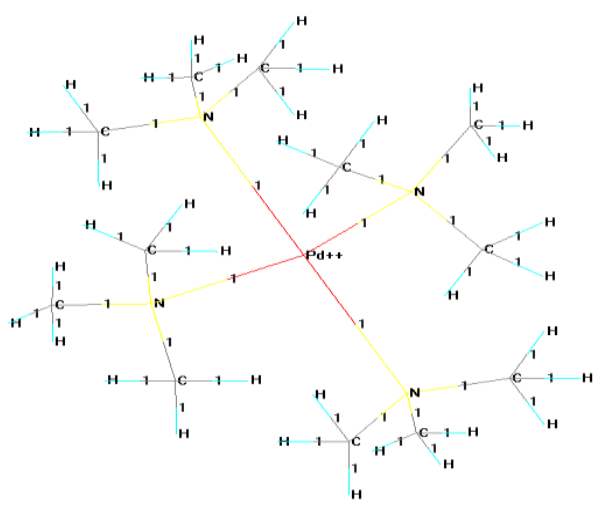

Figure 3. Bond order of palladium (II) complex ions with different amine ligands

L01

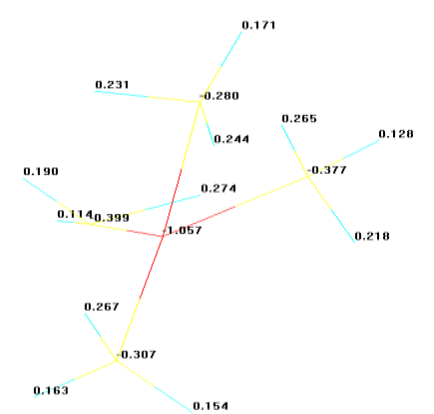

L03

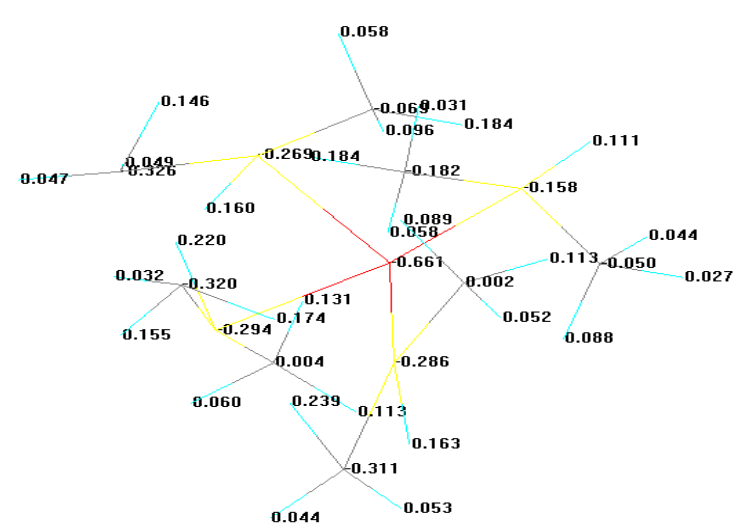

L02

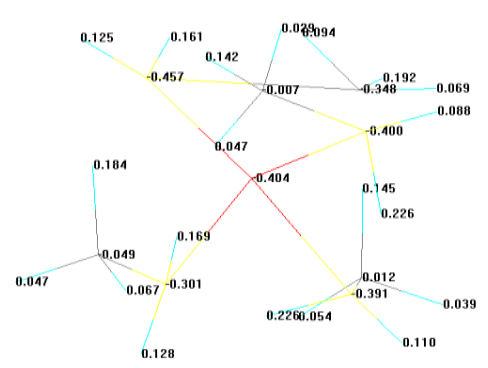

L04

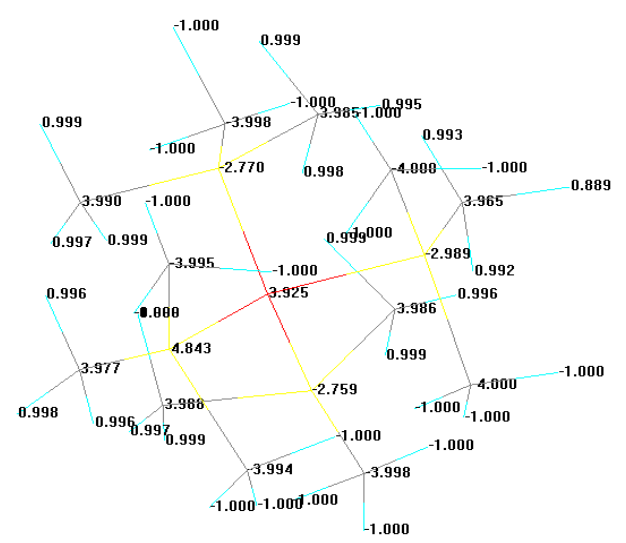


Figure 4. Atomic charge of palladium (II) complex ions with different amine ligands
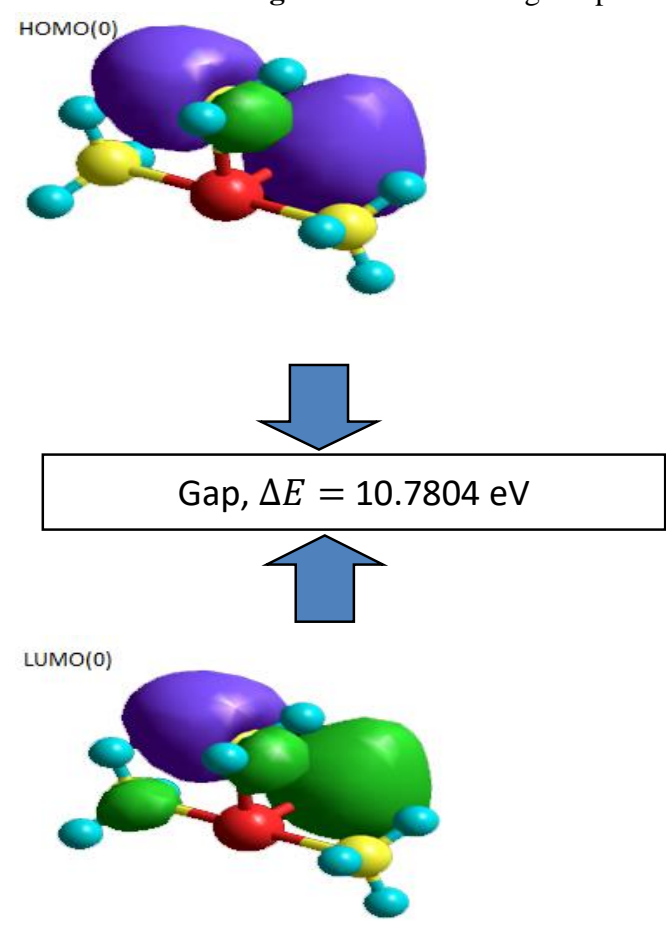

L03
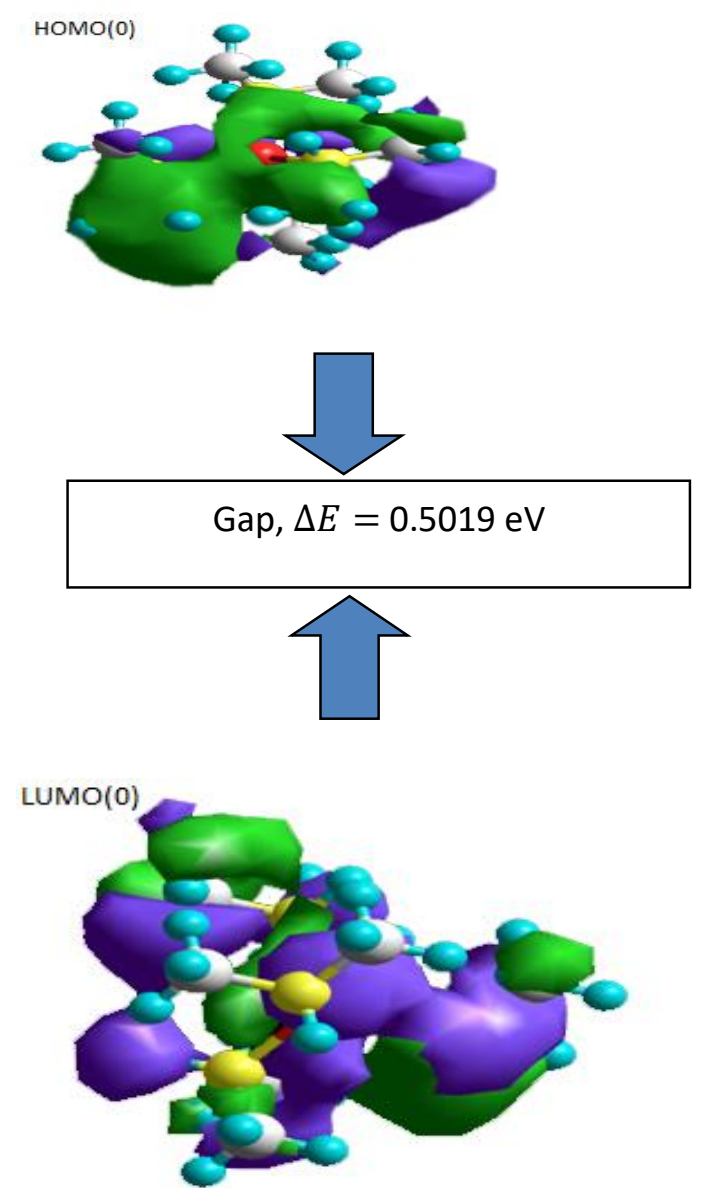

номо(0)
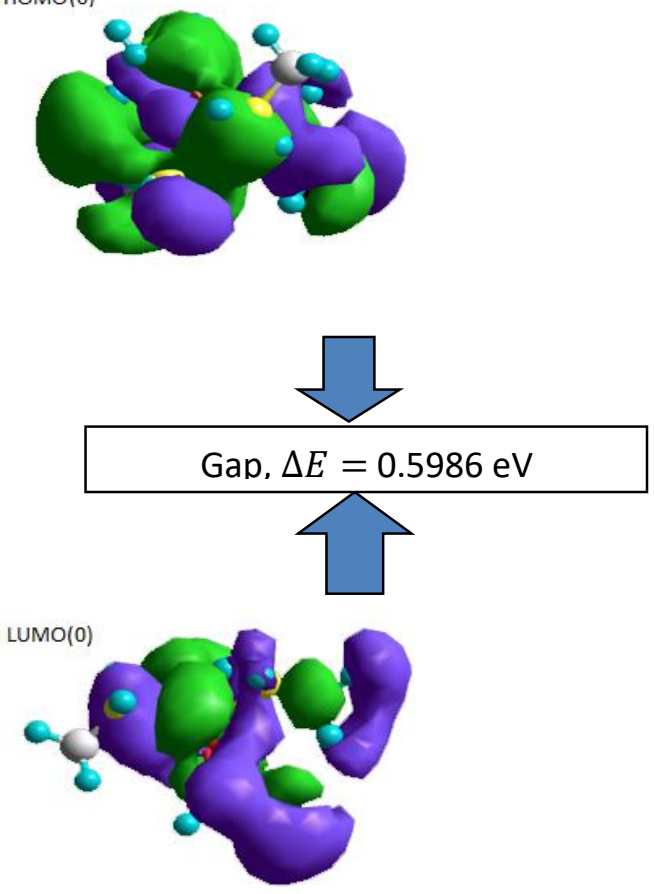

L04
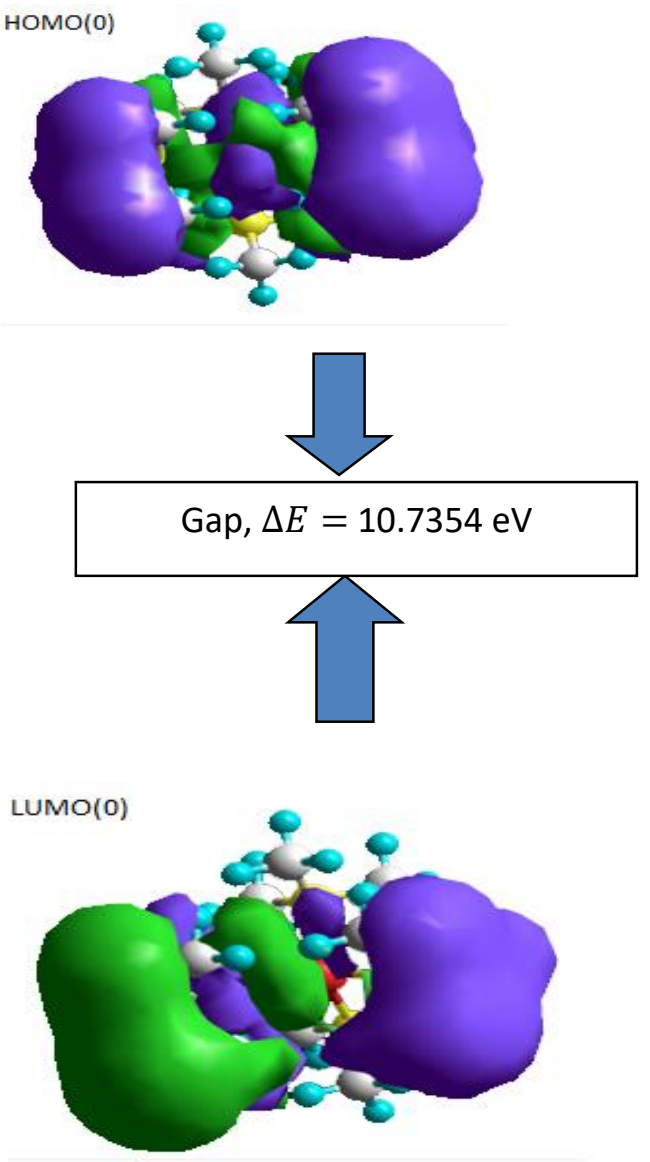

Figure 5: Orbital picture of HOMO and LUMO palladium (II) complex ions with different amine ligands 


\subsection{HOMO-LUMO}

The energy levels of the molecular orbitals order HOMO and LUMO for palladium (II) complexes ion with different amine ligands give information on the possible electronic transition and chemical stability. The HOMO and LUMO also indicate the electrophilic and nucleophilic attraction region in the molecule. The LUMO-HOMO gap is the most important parameter for chemical reactivity [28].

Table 1. Data for HOMO LUMO in different transition state

\begin{tabular}{lcccc}
\multicolumn{7}{c}{ Table 1. Data for HOMO LUMO in different transition state } \\
\hline L01 & L02 & L03 & L04 \\
\hline HOMO(0), eV & -16.1487 & -18.05713 & -23.64721 & -37.68882 \\
HOMO(-1), eV & -5.360071 & -17.45854 & -23.14531 & -26.95374 \\
HOMO(-2), eV & -4.970126 & -17.22483 & -21.69175 & -19.8055 \\
LUMO, (0), eV & -5.360071 & -17.45854 & -23.14531 & -26.95374 \\
LUMO, (-1), eV & -16.1487 & -18.05713 & -23.64721 & -37.68882 \\
LUMO, (-2), eV & -17.39359 & -18.3907 & -23.9424 & -37.84376 \\
\hline
\end{tabular}

\subsection{Chemical reactivity by DFT Calculations}

The Energy of the HOMO is directly related to the ionization potential and LUMO Energy is directly related to the electron affinity. The energy difference between HOMO and LUMO orbital is called an energy gap which is an important parameter that determines the stability of the structures. The energy gap is used in determining molecular electrical transport properties. In addition, according to Koopmans' theorem the energy gap, Egap, defined as the difference between HOMO and LUMO energy [29].
The shorter LUMO- HOMO gap is considered as the high reactivity, they are highlighted in figure 5 (color: green is a positive value and blue is a negative value). The HOMO can be through the outermost orbital containing electrons tends to give these electrons such as an electron donor. On the other hand, LUMO can be through the innermost orbital containing free places to accept an electron.

Table 2: Data for HOMO, LUMO, IP, EA, and LUMO- HOMO gap, $(\Delta \mathrm{E})$

\begin{tabular}{lcccc}
\hline & L01 & L02 & L03 & L04 \\
\hline HOMO, eV & -16.1487 & -18.0571 & -23.6472 & -37.6888 \\
LUMO, eV & -5.3601 & -17.4585 & -23.1453 & -26.9534 \\
$\Delta \mathrm{E}$, (LUMO-HOMO gap), eV & 10.7804 & 0.5986 & 0.5019 & 10.7354 \\
Ionization potential (I),eV & 16.1487 & 18.0571 & 23.6472 & 37.6888 \\
Electron affinity (A),eV & 5.3601 & 17.4585 & 23.1453 & 26.9534 \\
\hline
\end{tabular}

\subsection{Chemical reactivity by DFT Calculations}

Entropy and enthalpy is an important part of thermodynamics, which allows physics and physical chemistry to participate in any system throughout physical and chemical change. Entropy and enthalpy are closely related to each other.

$$
\mathrm{E}_{\text {gap }}=\left(\mathrm{E}_{\mathrm{LUMO}}-\mathrm{E}_{\mathrm{HOMO}}\right) \approx \mathrm{IP}-\mathrm{EA}
$$

The ionization potential (I) and electron affinity (A) can be estimated from the HOMO and LUMO energy values as following

$$
\begin{aligned}
& I=-E_{\text {Номо }} \\
& A=-E_{\text {LUMO }}
\end{aligned}
$$

Entropy can be understood as the discharge condition of any substance, i.e., whose entropy value is greater than its distortion in the reaction

of the participant. Table 3 shows that at the zero temperature without electric field, the value of 
entropy of optimized molecule is zero. On the other hand, it is found from table 4 that entropy and heat of capacity is increased with increasing temperature.

Table 3: Thermophysical properties

\begin{tabular}{|c|c|c|c|c|}
\hline Properties & L01 & L02 & L03 & L04 \\
\hline Total energy, $(\mathrm{kcal} / \mathrm{mol})$ & -3159536.19 & -3273037.55 & -3311028.49 & -3015629.47 \\
\hline Entropy, (kcal/mol-deg) & 0 & 0 & 0 & 0 \\
\hline Free energy, $(\mathrm{kcal} / \mathrm{mol})$ & -3159536.19 & -3273037.55 & -3311028.49 & -3015629.47 \\
\hline $\begin{array}{l}\text { Heat capacity, (kcal/mol- } \\
\text { deg) }\end{array}$ & 0 & 0 & 0 & 0 \\
\hline Dipole moment, (D) & 0 & 0 & 0 & 0 \\
\hline RMS gradient, $(\mathrm{kcal} / \mathrm{mol})$ & 0 & 0 & 0 & 0 \\
\hline Binding energy, $(\mathrm{kcal} / \mathrm{mol})$ & -3159536.19 & -3273037.55 & -3311028.49 & -3015629.47 \\
\hline Electronic energy, $(\mathrm{kcal} / \mathrm{mol})$ & -3580683.64 & -3976688.55 & -4438431.58 & -4654099.65 \\
\hline Nuclear energy, $(\mathrm{kcal} / \mathrm{mol})$ & 421147.450 & 703650.999 & 1127403.091 & 1638470.185 \\
\hline
\end{tabular}

Table 4: Entropy and Heat capacity in different temperature

\begin{tabular}{|c|c|c|c|c|c|c|}
\hline & \multicolumn{2}{|c|}{$273 \mathrm{~K}$} & \multicolumn{2}{|c|}{$298 \mathrm{~K}$} & \multicolumn{2}{|c|}{$323 \mathrm{~K}$} \\
\hline & Entropy & $\begin{array}{c}\text { Heat } \\
\text { capacity, } \\
\text { (kcal/mol- } \\
\text { deg) }\end{array}$ & Entropy & $\begin{array}{c}\text { Heat } \\
\text { capacity, } \\
\text { (kcal/mol- } \\
\text { deg) }\end{array}$ & Entropy & $\begin{array}{c}\text { Heat } \\
\text { capacity, } \\
(\mathrm{kcal} / \mathrm{mol}- \\
\text { deg) })\end{array}$ \\
\hline L01 & 0.07008 & 0.010338 & 0.0712 & 0.0107 & 0.0722 & 0.0112 \\
\hline L02 & 0.07046 & 0.007458 & 0.0713 & 0.0077 & 0.0721 & 0.0080 \\
\hline L03 & 0.07200 & 0.007138 & 0.0729 & 0.0074 & 0.0737 & 0.0077 \\
\hline L04 & 0.07498 & 0.008278 & 0.0758 & 0.0085 & 0.0768 & 0.0088 \\
\hline
\end{tabular}

\subsection{Vibrational spectrum}

The vibrational spectrum is the characteristic peak of any molecule for identification similar to the FTIR peak. To optimize these molecules for vibrational peak obtain the identified peak in the different region about 0 to $5800 \mathrm{~cm}^{-1}$ at which the main characteristic peak of tetraamine palladium(II) complex ion is almost 4200-4300, $3825-3900$ and $3600-3550 \mathrm{~cm}^{-1}$ and represented in fig-06.

L 01

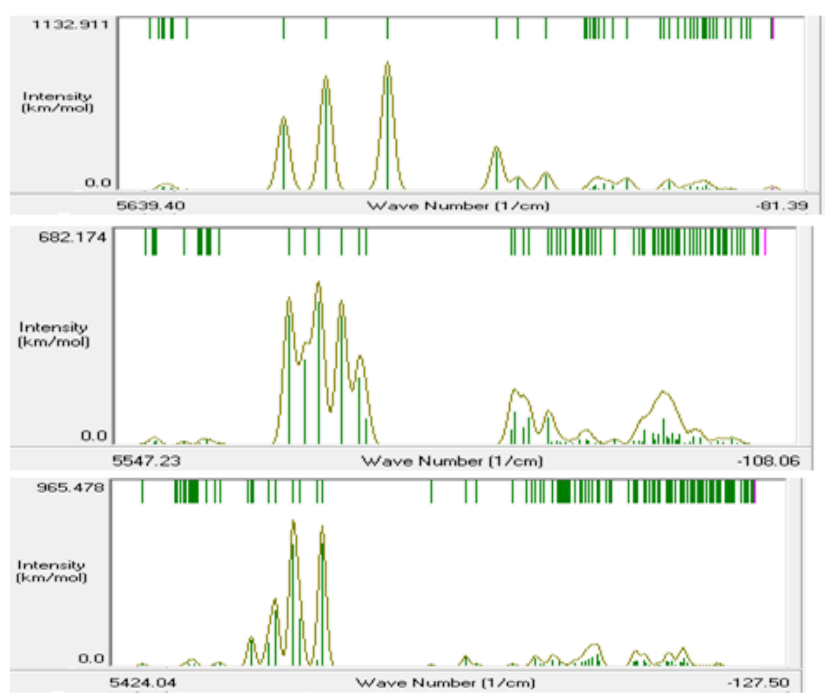


L 04

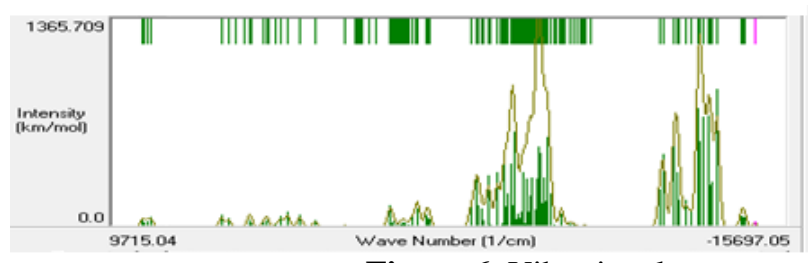

Figure 6. Vibrational spectrum

Table 5. Data for a vibrational spectrum of palladium (II) complex ions

\begin{tabular}{llllll}
\hline & $\begin{array}{l}\text { Normal } \\
\text { mode }\end{array}$ & Degeneracy & Frequency & Intensity & Symmetry \\
\hline L01 & 1 & 1 & 178.65 & 18.201 & $1 \mathrm{~A}$ \\
L02 & 1 & 1 & 149.0 & 0.994 & $1 \mathrm{~A}$ \\
L03 & 1 & 1 & 124.84 & 0.517 & $1 \mathrm{~A}$ \\
L04 & 1 & 1 & -14541.96 & 37.383 & $1 \mathrm{~A}$ \\
\hline
\end{tabular}

\subsection{UV-visible Spectrum}

UV-visible Spectrum provides a powerful technique by which the nature of metal ligands bonding may be identified. A remarkable covalency between almost all of the upper filled molecular orbitals of the ligand cluster and the metal d orbitals of suitable symmetry can be calculated. Those interactions which arise from ligand orbitals of $n$ symmetry primarily involve filled metal 4dxz and 4dyz orbitals and, although of importance, do not result in significant Pd (II) overlap since contributions due to filled bonding and anti-bonding levels tend to cancel one another. However, the interactions with orbitals of symmetry involve empty $4 \mathrm{dxy}$ and 5 s metal orbitals and result in important ligand-to-metal charge transfer [30].

The UV-visible spectrum of the tetra-amine palladium (II) complex ion shows in fig 7 with table 6, a strong transition (e near 250 and 360 $\mathrm{nm}$, as well as an ultraviolet band of weaker intensity near $320 \mathrm{~nm}$.

L01

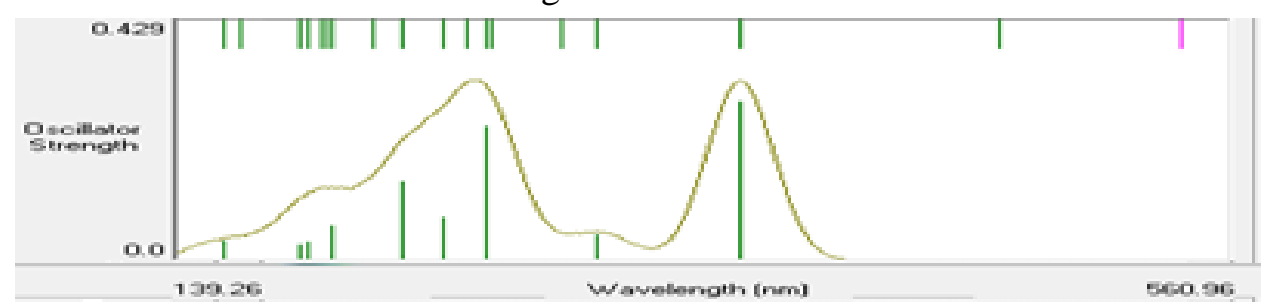

L02

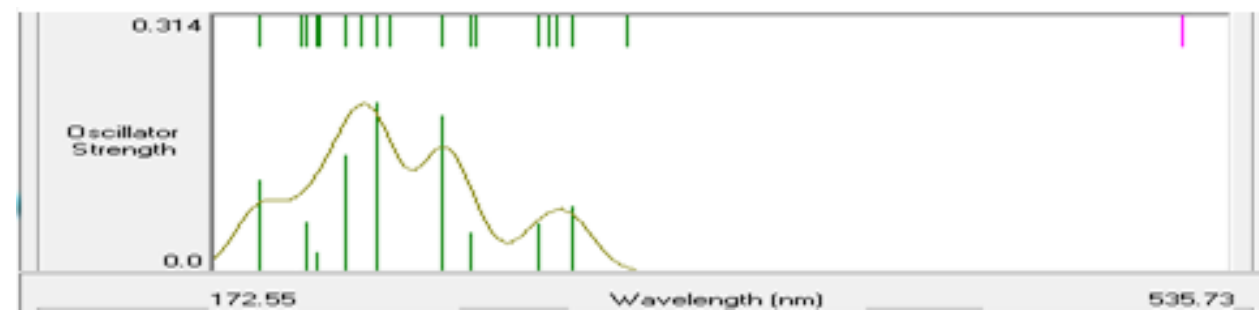

L03

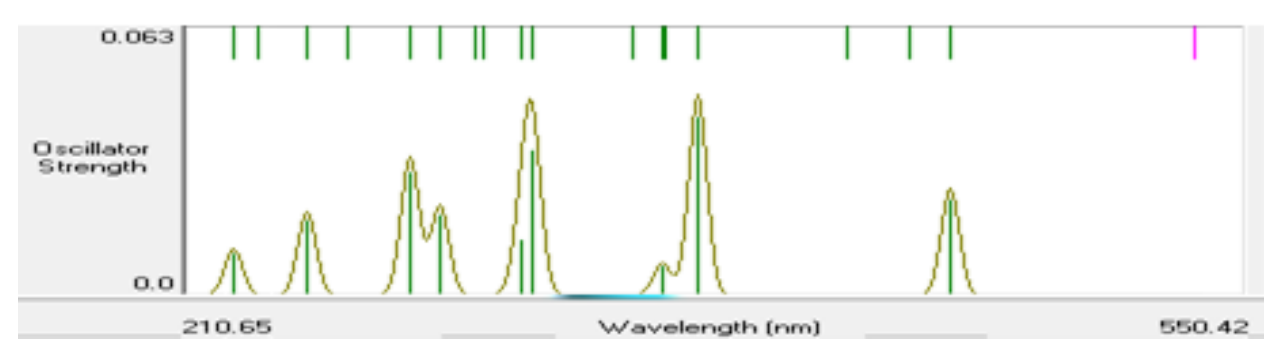




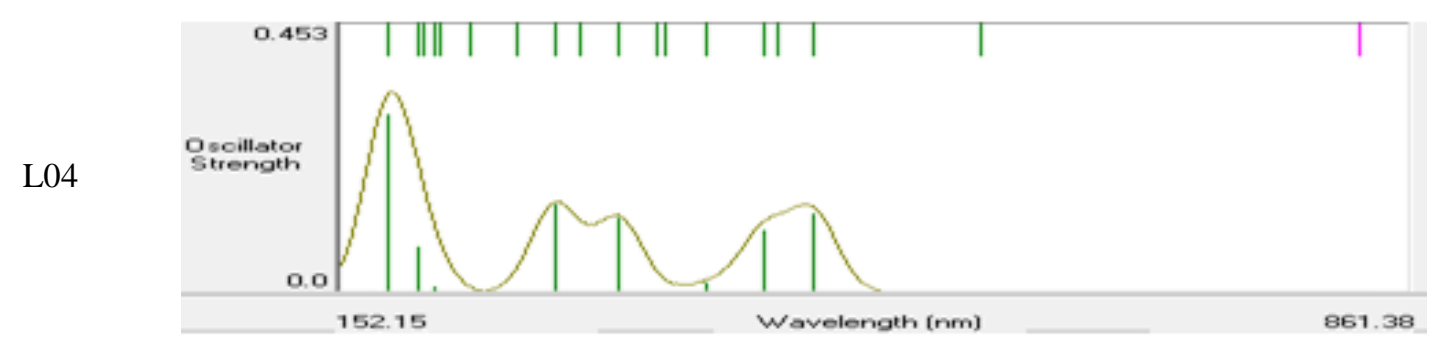

Figure 7: UV-visible Spectrum

Table 6. Data for different transition state, spin multiplicity, wavelength and oscillator strength for UV -visible spectrum

\begin{tabular}{llllll}
\hline & Transition & Degeneracy & $\begin{array}{l}\text { Spin } \\
\text { Multiplicity }\end{array}$ & Wavelength & $\begin{array}{l}\text { Oscillator } \\
\text { Strength }\end{array}$ \\
\hline L01 & 1 & 1 & Triplet & 541.79 & 0.0 \\
L02 & 1 & 1 & Triplet & 519.22 & 0.0 \\
L03 & 1 & 1 & Triplet & 534.98 & 0.0 \\
L04 & 1 & 1 & Triplet & 829.14 & 0.0 \\
\hline
\end{tabular}

\section{THE BIOLOGICAL ACTIVITY OF OPTIMIZED MOLECULES}

4.1. The distribution electrostatic potential in case of 3D mapped structure

The stability of the studied molecular structure is given by the higher negative values of total energy. The biological activity of a compound can be estimated on the basis of the energy difference $\Delta \mathrm{E}$ frontier orbitals given in table-07. This difference, $\Delta \mathrm{E}$ represents the electronic excitation energy which is possible in a molecule. The electrostatic potential in view of the 3D mapped structure in fig 08 indicates positive and negative charge region and the charged surface area in a molecule that is considered as the best tools to estimate the biological activity parameter [31].

According to the mechanism of antimicrobial activity and antimicrobial agents of bioactive L01

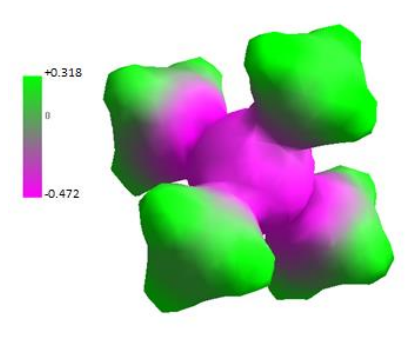

L03 molecules, the positive charge end of molecules is responsible to damage the plasma membrane of pathogens [32]. To kill the different human pathogenic microorganism, the region of molecules was used the positive charge area of the molecule. In this case, the most important factors are explained that the higher surface area having a positive charge is considered as the high antimicrobial activity.

The three-dimensional geometry of molecular electrostatic potential distribution highlights the existence of three regions with increased electronegativity in the whole molecule of L01, L02 and highly positivity in L03 and L04 shown in fig-08 and which play a role in their coupling to different structures in which ions are positively charged.

L02

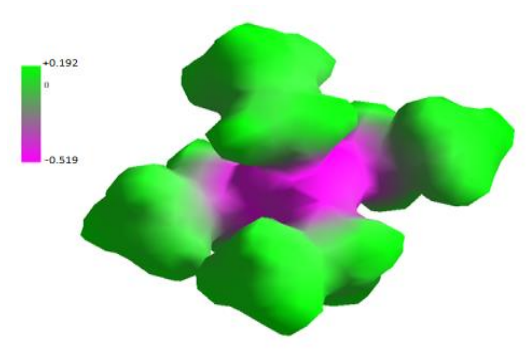

L04 

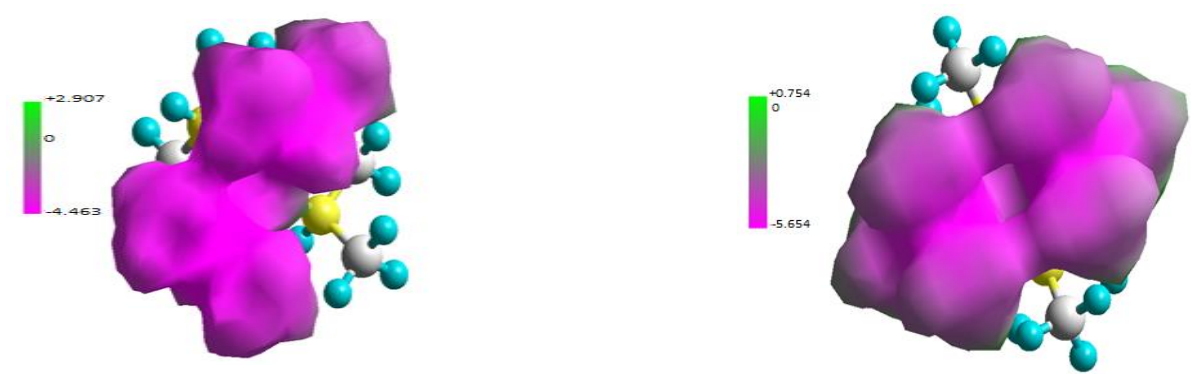

Figure 8: The 3D geometry of the distribution electrostatic potential

Table 7. Data of electrostatic potential energy difference of two levels

\begin{tabular}{lllll}
\hline & L01 & L02 & L03 & L04 \\
E1 & +0.318 & +0.192 & +2.907 & +0.754 \\
E2 & -0.472 & -0.519 & -4.463 & -5.654 \\
$\Delta$ E= E2-E1 & -0.790 & -0.711 & -7.370 & -6.408 \\
\hline
\end{tabular}

Here, E1 = Electrostatic potential energy in positive value, E2 = Electrostatic potential energy in negative value and $\Delta \mathrm{E}=$ Electrostatic potential energy difference of two level.

\subsection{Chemical reactivity}

The HOMO and LUMO energies are used for the determination of global reactivity descriptors. It is important that electrophilicity $(\omega)$, the chemical potential $(\mu)$, electronegativity $(\chi)$, hardness $(\eta)$ and softness (S) be put into a molecular orbital's framework. We focus on the HOMO and LUMO energies in order to determine the interesting molecular/atomic properties and chemical quantities. These are calculated as following equations, and given in table 08 .
$(\mu)=-\frac{I+A}{2}$
$(\eta)=\frac{I-A}{2}$
$(S)=\frac{1}{\eta}$
$(\chi)=\frac{I+A}{2}$
$(\omega)=\frac{\mu^{2}}{2 \eta}$

Table 8. Chemical reactivity

\begin{tabular}{lcccc}
\hline & L01 & L02 & L03 & L04 \\
\hline Hardness, $(\eta)$ & 5.3943 & 0.2993 & 0.2509 & 5.3677 \\
Softness, $(S)$ & 0.1854 & 3.3411 & 3.9856 & 0.1863 \\
Electrophilicity $(\omega)$, & 10.7203 & 526.7949 & 1090.8466 & 97.3092 \\
Chemical potential, $(\mu)$ & -10.7544 & -17.7578 & -23.3963 & -32.3211 \\
Electronegativity, $(\chi)$ & 10.7544 & 17.7578 & 23.3963 & 32.3211 \\
\hline
\end{tabular}

\subsection{Quantitative structure - activity relationships (QSAR)}

The molecule with minimum binding energy will have the maximum binding affinity and having the maximum binding affinity, indicating as the best molecule for drug leads molecules targeting computationally. In case of the biological activity of a molecule, the surface area is considered as an important parameter. Greater charge surface area of a molecule can be able to kill more pathogens. The greater positive charge surface area means a higher biological activity. On the other hand, a negative value of $\log \mathrm{P}$ indicates the hydrophilicity and positive $\operatorname{LogP}$ indicates the hydrophobicity that plays an important role in biochemical interactions and bioactivity [33, 34]. 
Hydrophobic drugs tend to be more toxic because, in general, are kept

longer, have a wider distribution in the body, are somewhat less selective in their binding to molecules and finally are often extensively metabolized.

Finally, the correlation of L01, L02, L03, and L04 complexes ion are increased the biological activity as increasing the size of ligands with fine correlation showing in table 09 .

\subsection{Calculation of PIC50}

The correlation between the biological activity and descriptor is developed by Zineb Almi et.al. 2014 [35] for the PIC50 value calculation from the Hyperchem simulation value that is given in the following equation as:

$$
\begin{aligned}
\text { PIC50 }=3.028 & -0.542 \log \mathrm{P}+0.352 \mathrm{HE}-1.272 \mathrm{Pol} \\
& +0.863 \mathrm{MR}-0.038 \mathrm{MV} \\
& -0.024 \mathrm{MW}+19.120 \mathrm{q} 01 \\
& +0.024 \mathrm{SAG}
\end{aligned}
$$

Here, $\mathrm{HE}=$ Hydration Energy, Pol = Polazibility, $\mathrm{MR}=$ Molecular Refractivity, $\log \mathrm{P}=$ Partition coefficient, $\mathrm{MV}=$ Molar Volume, $\mathrm{MW}=$ Molar Weight, SAG = Surface Area Grid, q01 = atomic net charges.

According to Zineb Almi et.al. 2014 [35], the biologically active molecule have PIC50 less value -200. From the table 10, the computed molecule of palladium (II) complex ion has the value of more 20 to 225 that means have biological activity and increasing length or number of methyl groups in amine ligands, the biological activity increases. In the L03 and L04 have the highest biological activity near to standard bioactive molecules.

Table 9. Data for QSAR study

\begin{tabular}{lcccc}
\hline & L01 & L02 & L03 & L04 \\
\hline Partial charge (e) & 0.00 & 0.00 & 0.00 & 0.00 \\
Surface Area(grid), & 286.86 & 365.65 & 412.23 & 439.46 \\
Volume, $\AA^{3}$ & 401.50 & 586.90 & 713.83 & 806.95 \\
Hydration Energy kcal/mol & -43.34 & -10.91 & 0.86 & 4.79 \\
Log P & -3.91 & -2.93 & -1.94 & -0.95 \\
Refractivity $\AA^{3}$ & 9.60 & 29.19 & 48.77 & 68.36 \\
Polarizibility, $\AA^{3}$ & 4.74 & 12.08 & 19.42 & 26.76 \\
Mass (amu) & 174.52 & 230.63 & 286.74 & 342.84 \\
\hline
\end{tabular}

Table 10. Data of PIC50

\begin{tabular}{ccccc}
\hline & L01 & L02 & L03 & L04 \\
PIC50 & -20.41 & -8.46 & -1.69 & 1.83 \\
\hline
\end{tabular}

\subsection{Correlation and comparison study in case of substituent groups in amine ligands}

In the case of chemical reactivity, the LUMOHOMO gap in presence of $\mathrm{H}$ atom in $\mathrm{NH}_{3}$ and $3 \mathrm{CH}_{3}$ in $\mathrm{N}$-atom is 10.7804 and $10.7354 \mathrm{eV}$ which is larger value meaning lower reactivity and almost the same. On the other hand, attaching one and two methyl group in amine ligand, the LUMO-HOMO gap is 0.5986 and $0.5019 \mathrm{eV}$ which means that attaching two methyl groups has higher reactivity that one methyl group.

The most important comparison in thermophysical properties is explained that with increasing the temperature, the entropy and heat capacity increases in poor amount and with increasing methyl group in amine ligand the entropy change is an amount of 0.000 .00038 , 0.00154 and $0.0029 \mathrm{kcal} / \mathrm{mol}$. The heat capacity 
is also decreased as $3 \mathrm{CH}_{3}<2 \mathrm{CH}_{3}<\mathrm{CH}_{3}<\mathrm{H}$ or

primary $<$ secondary $<$ tertiary.

\begin{tabular}{|c|c|c|c|c|c|c|}
\hline & \multicolumn{2}{|c|}{$\mathrm{Pi}, \pi$} & \multicolumn{2}{|c|}{ Refractivity, (MR) } & \multicolumn{2}{|c|}{ Surface Area, (SA) } \\
\hline $\mathrm{Pi}, \pi$ & & $\begin{array}{c}\text { Biological } \\
\text { activity }\end{array}$ & & $\begin{array}{c}\text { Biological } \\
\text { activity }\end{array}$ & SA & $\begin{array}{c}\text { Biological } \\
\text { activity }\end{array}$ \\
\hline $\mathrm{H}$ & 0.0 & -- & 0.0 & - & 0.0 & Correlation \\
\hline $\mathrm{CH}_{3}$ & -0.98 & Less & +19.59 & Less & +78.79 & occurs \\
\hline $2 \mathrm{CH}_{3}$ & -1.97 & Less & +39.17 & Less & +125.37 & \\
\hline $3 \mathrm{CH}_{3}$ & -2.96 & Less & +58.76 & Less & +152.60 & \\
\hline
\end{tabular}

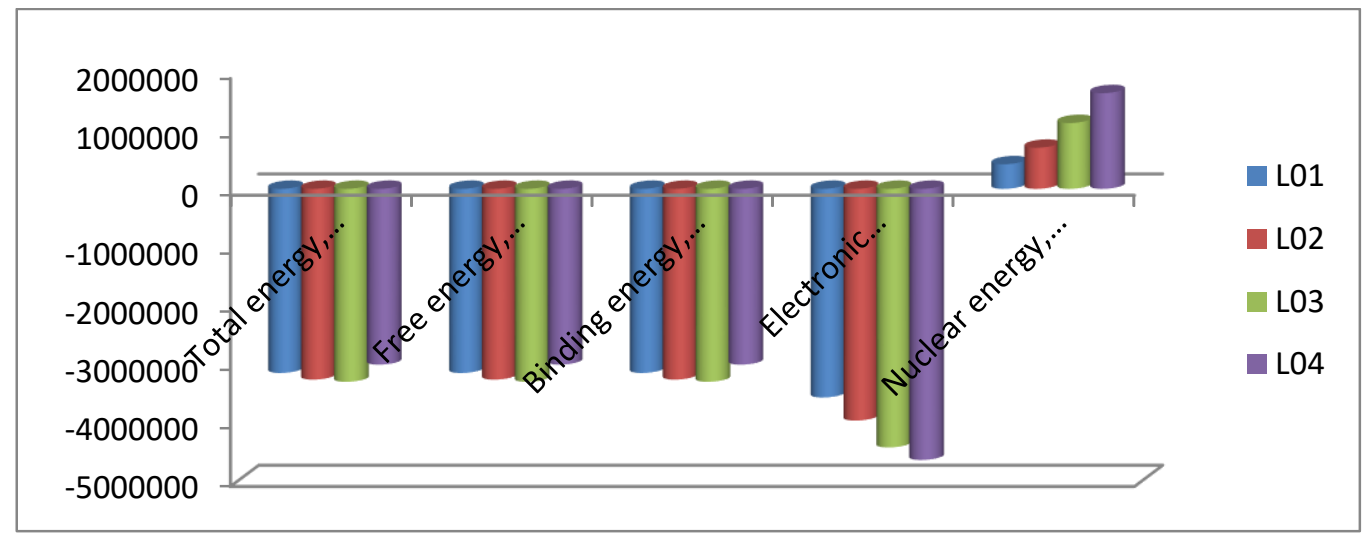

Figure 9. Comparison of thermophysical properties

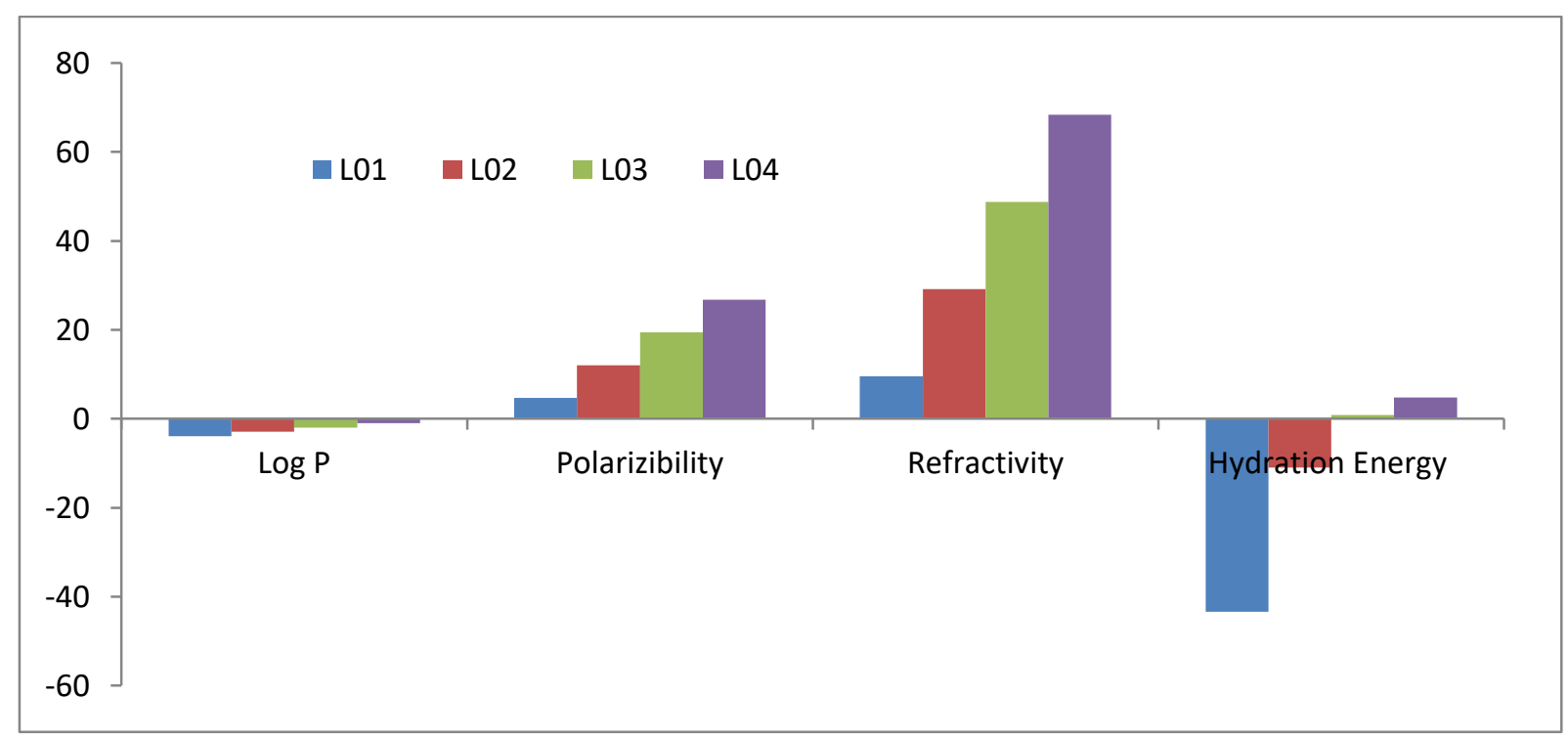

Figure 10. Comparison of QSAR 


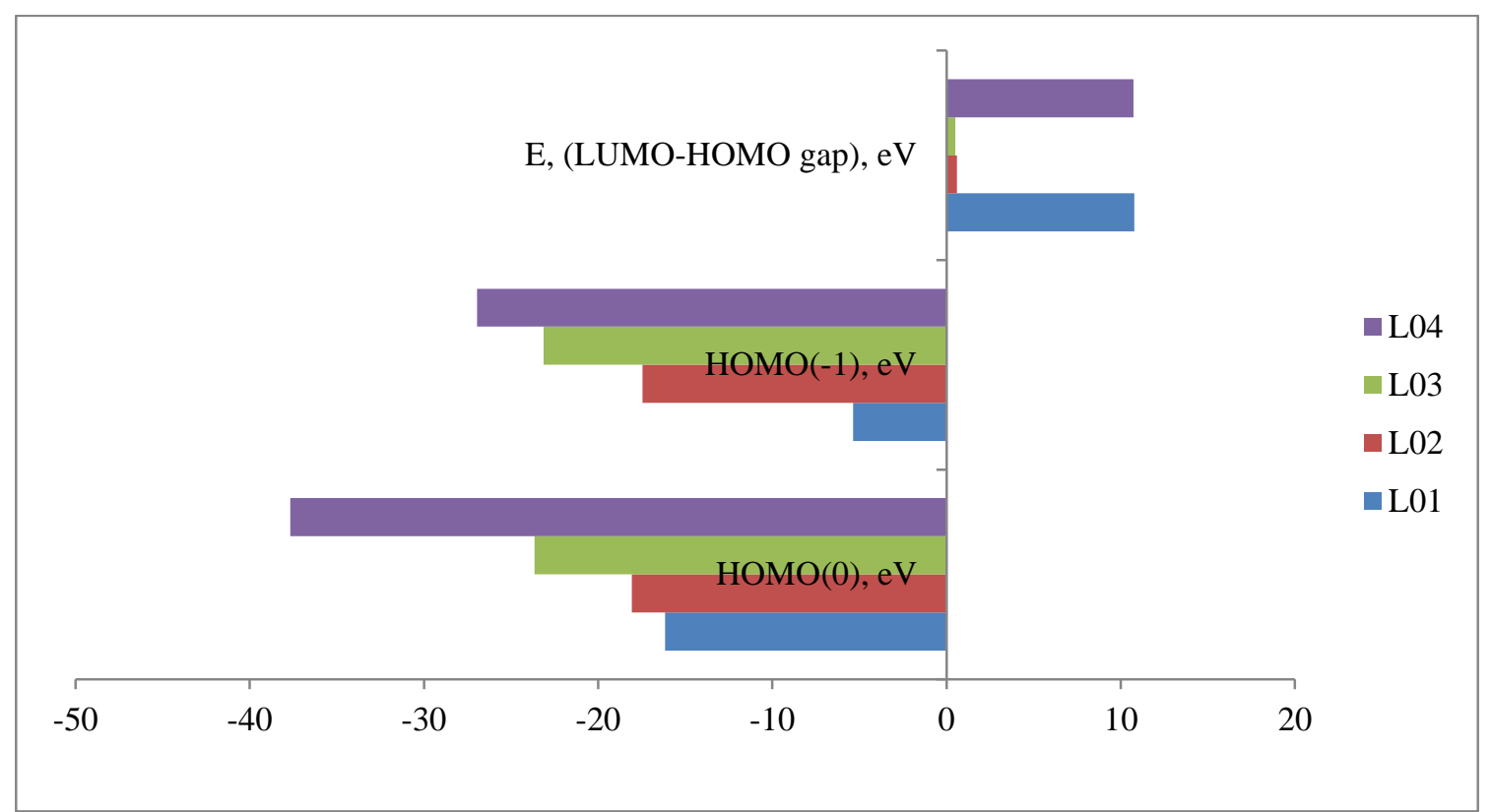

Figure 11. Comparison of the gap with chemical reactivity

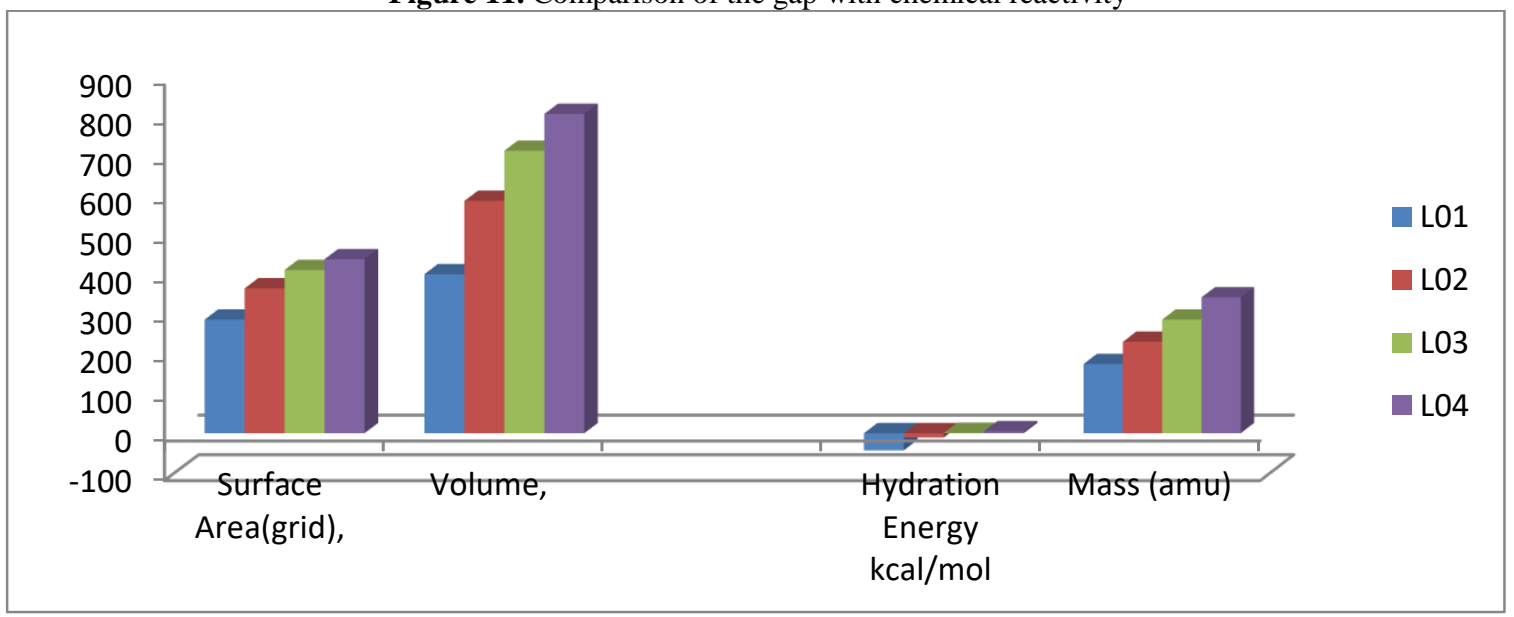

Figure12. Comparison of molecular properties

From figure 9, 10, 11, 12, it was found that biological activity increases with the increase the alkyl groups in palladium (II) complex ions.

\section{CONCLUSION}

The DFT method was used to characterize and optimize of palladium (II) complex ions with amine ligands and the thermophysical and chemical and biological properties were recorded. From the spectroscopy studies, the vibration, degeneracy, symmetry, and splitting of d orbitals give the information in the analytical method. In the case of HOMO, LUMO, and HOMO - LUMO gap can be informed that palladium (II) complex ions with amine ligands are chemically reactive for further uses. As the value of $\log P$ is negative, palladium (II) complex ions with amine ligands are hydrophilic nature that is why the toxicity is very less and supports the safe uses in all areas.

\section{ACKNOWLEDGMENTS}

I am thankful to Professor Dr. Parimal Bala, Professor Dr. Kamrul Alam Khan and Professor Dr. Ainul Huda, Department of Physics, Jagannath University, Dhaka-1100, and Bangladesh for his inspiration to carry on our research.

\section{REFERENCES}

[1] Valderrama S., Van Roekel N., Andersson M., Goodacre C. J., Munoz C. A., A comparison of the marginal and internal adaptation of titanium and gold-platinum-palladium metal ceramic crowns, International Journal of Prosthodontics, 1995. 8(1). 
[2] Atkinson R.H., A volumetric method for the rapid assay of palladium jewellery alloys, Analyst, 79-939 (1954) 368-370.

[3] Faurschou A., Kapa E. A., Metal allergen of the 21st century-a review on exposure, epidemiology and clinical manifestations of palladium allergy, Contact Dermatitis, 64-4 (2011) 185-195.

[4] Garrett C. E. P., Kapa, The art of meeting palladium specifications in active pharmaceutical ingredients produced by Pdcatalyzed reactions, Advanced Synthesis \& Catalysis, 346-8 (2004) 889-900.

[5] Torborg C., Beller M., Recent applications of palladium-catalyzed coupling reactions in the pharmaceutical, agrochemical, and fine chemical industries, Advanced Synthesis \& Catalysis, 351-18 (2009) 3027-3043.

[6] Doucet H. H., Jean-Cyrille, Palladium coupling catalysts for pharmaceutical applications, Current opinion in drug discovery \& development, 10-6 (2007) 672-690.

[7] Ray S., Mohan R., Singh J. K., Samantaray MK, Shaikh MM., Anticancer and antimicrobial metallopharmaceutical agents based on palladium, gold, and silver N-heterocyclic carbene complexes, Journal of the American Chemical Society, 129-48 (2007) 15042-15053.

[8] Schmidt A., Molano V., Hollering M., Pöthig A., Casini A., Kühn F. E., Evaluation of new palladium cages as potential delivery systems for the anticancer drug cisplatin, Chemistry-A European Journal, 22-7 (2016) 2253-2256.

[9] Khan H., Badshah A., Murtaz G. , Said M., Rehman Z.-ur, Neuhausen C., Todorova M., Jean-Claude B. J., Butler I. S., Synthesis, characterization and anticancer studies of mixed ligand dithiocarbamate palladium (II) complexes, European journal of medicinal chemistry, 46-9 (2011) 4071-4077.

[10] Rebolledo A. P., Vieites M., Gambino D., Piro O. E., Castellano E. E., Palladium (II) complexes of 2-benzoylpyridine-derived thiosemicarbazones: spectral characterization, structural studies and cytotoxic activity, Journal of inorganic biochemistry, 99-3 (2005) 698706.

[11] Matesanz, A. I. P., José M., Navarro P., Moreno
J. M., Colacio E., Souza P., Synthesis and characterization of novel palladium (II) complexes of bis (thiosemicarbazone). Structure, cytotoxic activity and DNA binding of Pd (II)-benzyl bis (thiosemicarbazonate), Journal of inorganic biochemistry, 76-1 (1999) 29-37.

[12] Ohff M., Ohff A., van der Boom M. E., Milstein D., Highly active Pd (II) PCP-type catalysts for the Heck reaction, Journal of the American Chemical Society, 119-48 (1997) 11687-11688.

[13] Old D. W., Wolfe J. P., Buchwald S. L., A highly active catalyst for palladium-catalyzed cross-coupling reactions: room-temperature Suzuki couplings and amination of unactivated aryl chlorides, Journal of the American Chemical Society, 120-37 (1998) 9722-9723.

[14] Dai C. F., Gregory C., The first general method for palladium-catalyzed Negishi cross-coupling of aryl and vinyl chlorides: use of commercially available $\mathrm{Pd}(\mathrm{P}(\mathrm{t}-\mathrm{Bu}) 3) 2$ as a catalyst, Journal of the American Chemical Society, 123-12 (2001) 2719-2724.

[15] Shapiro A. H., The Dynamics and Thermodynamics of Compressible Fluid Flow: In Two Volumes. 1953: Wiley.

[16] Von Bertalanffy L., The theory of open systems in physics and biology, Science, 111-2872 (1950) 23-29.

[17] Frank H. S., Evans M. W., Free volume and entropy in condensed systems III. Entropy in binary liquid mixtures; partial molal entropy in dilute solutions; structure and thermodynamics in aqueous electrolytes, The Journal of Chemical Physics, 13-11 (1945) 507-532.

[18] Guggenheim E. A., Thermodynamics-an advanced treatment for chemists and physicists, Amsterdam, North-Holland, 414 (1985) 1985.

[19] Hossain M. I., Ajoy K., Synthesis and Characterization of Ammonium Ionic Liquids and Their Antimicrobial and Computational Overview, Asian journal of chemical science, 34 (2018) 1-10.

[20] Hossain M. I., Kumer A., Begum S. H., Synthesis and Characterization of Ammonium Benzoate and Its Derivative Based Ionic Liquids and Their Antimicrobial Studies, Asian 
journal of physical and chemical science, 3-4 (2018) 1-9.

[21] Becke, A. D., Density-functional thermochemistry. III. The role of exact exchange, The Journal of chemical physics, 987 (1993) 5648-5652.

[22] Janak, J. F., Proof that $\partial$ E $\partial \mathrm{n} i=\varepsilon$ in densityfunctional theory, Physical Review, 18-12 (1978) 7165.

[23] Howard A., McIver J., Collins J., Hyperchem computational chemistry, Hypercube Inc., Waterloo, 1994.

[24] Gill P. M. J., Johnson B. G., Pople J. A., Frisch M. J, The performance of the Becke-LeeYang-Parr (B-LYP) density functional theory with various basis sets, Chemical Physics Letters, 197-4,5 (1992) 499-505.

[25] Miehlich B., Savin A., Stoll H., Preuss H., Results obtained with the correlation energy density functionals of Becke and Lee, Yang and Parr, Chemical Physics Letters, 157-3 (1989) 200-206.

[26] Lechner W., Dellago C., Accurate determination of crystal structures based on averaged local bond order parameters, The Journal of chemical physics, 129-11 (2008) 114707.

[27] Kumer A., Ahmed B., Sharif Md A., Al-Mamun A., A Theoretical Study of Aniline and Nitrobenzene by Computational Overview, Asian journal of physical and chemical science, 4-2 (2017) 1-12.

[28] Koopmans Y. T., Uber die zuordnung von wellenfunktionen und eigenwerten $\mathrm{zu}$ den,einzelnen elektronen eines atoms, Physica, 1-1,6 (1934) 104-113.

[29] Canadell E., Ravy S., Pouget J. P., Brossard L., Concerning the band structure of $\mathrm{D}$ (M (dmit) 2) $2(\mathrm{D}=\mathrm{TTF}, \mathrm{Cs}, \mathrm{NMe} 4) ; \mathrm{M}=\mathrm{Ni}, \mathrm{Pd})$ molecular conductors and superconductors: Role of the M (dmit) 2 Homo and Lumo, Solid State Communications, 75-8 (1990) 633-638.

[30] Böhm M., Stürzebecher J, Klebe G., Threedimensional quantitative structure- activity relationship analyses using comparative molecular field analysis and comparative molecular similarity indices analysis to elucidate selectivity differences of inhibitors binding to trypsin, thrombin, and factor $\mathrm{Xa}$, Journal of medicinal chemistry, 42-3 (1999) 458-477.

[31] Timofeeva L., Kleshcheva N., Antimicrobial polymers: mechanism of action, factors of activity, and applications, Applied microbiology and biotechnology, 89-3 (2011) 475-492.

[32] Kumer A., Sarker N., Paul S., Zannat A., The Theoretical Prediction of Thermophysical properties, HOMO, LUMO, QSAR and Biological Indics of Cannabinoids (CBD) and Tetrahhdrocannabinol (THC) by Computational Chemistry, Advanced Journal of Chemistry, 33 (2019) 1-13.

[33] Kumer A., Sarker M. N., Paul S., The theoretical investigation of HOMO, LUMO, thermophysical properties and QSAR study of some aromatic carboxylic acids using HyperChem programming, International Journal of Chemistry and Technology, 3-1 (2019) 26-37.

[34] Almi Z., Belaidi S., Lanez T., Tchour N., Structure Activity Relationships, QSAR Modeling and Drug-like calculations of TP inhibition of 1,3,4- oxadiazoline-2-thione Derivatives, International Letters of Chemistry, Physics and Astronomy, 37 (2014) 113-124. 